\title{
Dinamik Teslim Zamanı Atama Problemi için Holonik Sistem Tasarımı
}

\author{
Cenk ŞAHİN*1 \\ ${ }^{1}$ Çukurova Üniversitesi, Mühendislik Mimarlık Fakültesi, Endüstri Mühendisliği Bölümü, \\ Adana
}

Geliş tarihi: 15.01.2016 Kabul tarihi: 16.03 .2016

\section{Özet}

Teknolojide yaşanan hızlı ilerlemeler, müşteri isteklerindeki değişiklikler ve nispeten daha kısa ürün yaşam döngüsü üretim sistemlerini daha doğru teslim zamanları vermeye zorlamaktadır. Bu amaçla, üretim sistemlerinin performansını ve değişen müşteri isteklerine yanıt verme kalitesini geliştirmek için akademide ve endüstride birçok çalışma gerçekleştirilmiştir. Bu çalışmada, esnek bir üretim sistemi içerisinde gelen siparişlere teslim zamanı atayan etmen tabanlı holonik bir kontrol yapısı tasarımı önerilmiştir. Önerilen sistem dinamik bir ortamda çalışmaktadır ve atanan teslim zamanları etmenler arasındaki müzakereler sonucunda elde edilmektedir.

Anahtar Kelimeler: Teslim zamanı atama problemi, Holonik üretim sistemi, Çoklu-etmen sistemi

\section{Holonic System Design for Dynamic Due Date Assignment Problem}

\begin{abstract}
Rapid advances in technology, changes in customer demand and relatively short product life cycles force production systems to give a more accurate due dates. For this purpose, many studies were carried out in academia and industry to improve the performance and the quality of production systems to respond to changing customer requirements. In this study, an agent-based holonic control structure design that assigns the due dates for incoming orders in a flexible production system is proposed. The proposed system is working under a dynamic environment and assigned due dates are obtained as a result of negotiations between the agents.
\end{abstract}

Keywords: Due-Date assignment problem, Holonic manufacturing system, Multi-agent system

\footnotetext{
* Yazışmaların yapılacağı yazar: Cenk ŞAHİN, Mühendislik Mimarlık Fakültesi, Endüstri Mühendisliği Bölümü, Adana. cenksahin@cu.edu.tr
} 


\section{GíRiş}

Esnek üretim sistemleri, 20. Yüzyılın sonlarına doğru rekabet edebilirliği oldukça yüksek bir üretim stratejisi olarak ortaya çıkmış ve geleneksel üretim sistemlerine göre orta çeşitlilik ve büyüklükteki ürünlerin üretilebileceği en uygun yol olarak kendini göstermiştir [1-3]. Esnek üretim sistemlerinde üretilen ürünleri, müşteriye rekabetçi piyasa koşulları altında zamanında teslim etmek çok önemlidir. Zamanında tamamlanamayan işler müşterinin güvenini sarsma ve piyasadaki itibarı kaybetme gibi cezalara neden olur. Bu yüzden teslim zamanlarını karşılamak birçok üretim yöneticisinin ana problemidir. Farklı müşterilere ait, farklı spesifikasyonlara sahip ürün çeşitlerinin değişik miktarlarını içeren siparişlerin mevcut zaman ve kaynak koşullarıyla müşteriye teslim tarihlerine yetiştirilmesi problemi literatürde de sıklıkla ele alınan konulardan biridir. Özellikle üretim sistemlerinde ortaya çıkan tam zamanında üretim (JIT) vb. kavramlar bu konudaki çalışmalara ağırlık verilmesini sağlamıştır. İşlem sureleri, iş üzerinde yapılacak işlem sayısı, kuyrukta bekleyen iş sayısı ve işlem sureleri, atölyede bulunan iş sayıları ve makineler arasında bekleme süreleri gibi faktörler dikkate alınarak çok sayıda teslim zamanı belirleme kuralı geliştirilmiştir [4, 5, 6]. Ancak günümüzde geliştirilen yöntemlerin, sistemde meydana gelen herhangi bir olaya, hata toleransina ve donanım/yazılımın yeniden şekillendirilmesine gerçek zamanlı olarak hızlı bir şekilde cevap vermesi istenmektedir. Birçok imalat modeli, bu ihtiyaçları karşıladığını vaat etmektedir. Son zamanlarda, bu modeller içerisindeki dağınık holonik üretim sistemleri ve akıllı üretim sistemleri (Etmen tabanlı üretim sistemleri) yaklaşımları akademide ve endüstride oldukça ilgi görmektedir.

Holonik üretim sistemi, gerçek zamanlı sistemlerin dinamik olarak kontrol etmek ve mevcut sistemlerde karşılaşılan birçok problemin üstesinden gelebilmek için üretim aktivitelerini organize eden nispeten yeni bir yaklaşımdır [7]. Holonik sistemlerin geliştirilmesinde etmen tabanlı sistemler çok önemli bir yer tutmaktadır. Daha genel bir bakış açısıyla değerlendirildiğinde, etmen tabanlı sistemler holonik sistemlerin uygulanabilmesi için genel yazılım teknolojisini ifade edebilmektedir ve dinamik ortamdaki karmaşık problemler için bir çözüm yaklaşımı olarak görülebilir [8, 9]. Üretim sistemleri içerisinde dinamik teslim zamanı çizelgeleme problemi literatürde sıklıkla çalışılmaktadır [1020] ancak holonik üretim sistemi yaklaşımı ile bu problemi çözmeye çalışan araştırma sayısı oldukça azdır. Bu konuda yapılan çalışmalardan bazıları şunlardır. Liu ve ark. [9] kalıp endüstrisinde yeni gelen siparişlerin teslim zamanının atanması için çoklu etmen tabanlı taslak modelini geliştirmişlerdir. Rajabinasab ve Mansour [21] stokastik iş gelişleri, belirsiz işlem süreleri ve beklenmeyen makine bozulmalarını göz önüne alarak esnek bir atölye problemi sunmuşlardır. Çözüm için çoklu etmen sistemi geliştirmişlerdir. Elde edilen çıktılara göre etmen tabanlı yöntem daha iyi sonuçlar vermiştir. Yin ve ark. [22] tek bir makinede atanabilir teslim zamanlarını ele almışlardır. İşlerin tamamlanma zamanları ve teslim tarihleri etmen tabanlı sistemler kullanılarak minimize edilmiştir.

$\mathrm{Bu}$ çalışmanın temel amacı, esnek bir üretim sistemi içerisinde dinamik olarak gelen siparişlere daha doğru bir teslim zamanı atayan etmen tabanlı holonik bir kontrol yapısı tasarımı geliştirmektir. Geliştirilecek olan sistemde yer alan her bir etmen, kendi kararlarını kendisi alabilecek özerklikte ve sistem içesinde yer alan diğer etmenlerle işbirliği ve müzakere yapabilecek yetenekte olacaktır.

\section{TESLIM ZAMANI ATAMA PROBLEMI İÇIN ÖNERILEN HOLONIK SISTEM}

Bir esnek üretim sisteminde yer alan makine ve malzeme taşıma sistemleri göz önüne alınarak belirlenecek olan teslim zamanı atama problemi için önerilecek olan holonik yapının tasarımı bu bölümde sunulacaktır.

\section{1. Üretim Sistemi Açısından Holonik Yapı}

PROSA, üretim sistemleri için PMA/K.U. Leuven 
de geliștirilmiş olan bir referans yapısıdır [23] ve birçok çalışmada holonik üretim sistemleri için referans yapı olarak alınmıştır. Bu referans yapısı üç adet temel holondan oluşmaktadır. $\mathrm{Bu}$ temel holonlar ürün (product), kaynak (resource), sipariş (order) holonlarıdır.

Bir kaynak holonu, bir üretim sistemindeki bir üretim kaynağı ya da o kaynağı yöneten bilgi işleme parçası gibi bir fiziksel parçadan oluşur. Kendisini çevreleyen holonlara üretim kapasitesini ve fonksiyonelliğini bildirir. Bir kaynak holonu fabrika, makineler, fırınlar, taşıyıcılar, boru hatları, paletler, parçalar, hammaddeler, takımlar, takım tutucular, hammadde stokları, personel gibi üretim metotlarının bir soyutlamasıdır. Bir ürün holonu, istenen kalitede ürünü üretebilmek için gerekli olan ürün ve süreç bilgisini bünyesinde barındırır. Bir ürün holonu, ürün yaşam döngüsü, kullanıcı istekleri, tasarım, süreç planları, kalite prosedürleri vb. ile ilgili güncel ve tutarlı bilgileri içerir. Bir ürün holonu, geleneksel olarak ürün dizaynı ile şekillenen fonksiyonellik, süreç planlama ve kalite güvenceyi kapsar.

Bir sipariş holonu ise bir üretim sistemindeki bir görevi temsil eder. Bir sipariş holonu atanan işin zamanında ve doğru bir şekilde yerine getirilmesi ile sorumludur. Sipariş holonu genellikle fabrika boyunca gideceği yeri yönetebilecek bir davranışa sahip bir iş parçası olarak görülür (Örneğin; diğer parçalarla ve üretim yaptırılacak kaynaklarla müzakere etmek için).

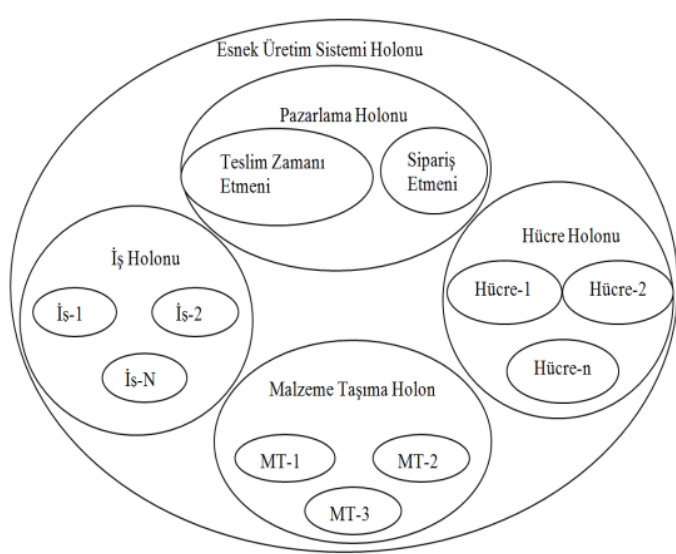

Şekil 1. Üretim sistemi açısından holonik yapı
Hücresel bir esnek üretim sisteminin kontrolü için önerilen holonik yap1, PROSA referans yapısındaki temel yapı blokları kullanılarak inşa edilmiştir. Bu önerilen yapı Şekil 1'de verilmiştir. Esnek üretim sisteminin tümü olarak bakıldığında sistemde iş, hücre, malzeme taşıma ve pazarlama holonlarından oluşmaktadır. Bu yapı fiziksel ve mantıksal holonlar diye ayırabileceğimiz iki parçadan oluşmaktadır. Bu holonlardan hücre holonu ve taşıma holonları fiziksel, iş ve pazarlama holonu ise mantıksal holonlardır. Holonun tanımı gereği her bir holon aynı zamanda bir alt holonun parçası da olabilmektedir. Esnek üretim sistemi en üst seviye holon olarak düşünüldüğünde pazarlama holonu, iş holonu, taşıma holonu ve hücre holonu esnek üretim sistemi holonunun bir alt parçasıdır ve aynı zamanda kendi içerisinde barındırdıkları holonların bütünüdür.

\subsection{1. Üretim Sisteminde Yer alan Holonlar}

Önerilen sistemdeki hücre holonu, makine, stok ve personel holondan oluşmaktadır. Holonik üretim sistemlerinde bir biri ile etkileşimde olan heterojen holonlar için personel etmene arabulucu rol verilir ve bir grup halindeki holonlar arasındaki etkileşimi yönetmesi sağlanır.

Önerilen sistemde yeralan iş holon ve taşıma holonları benzer bir yapıya sahiptir (Şekil 2).
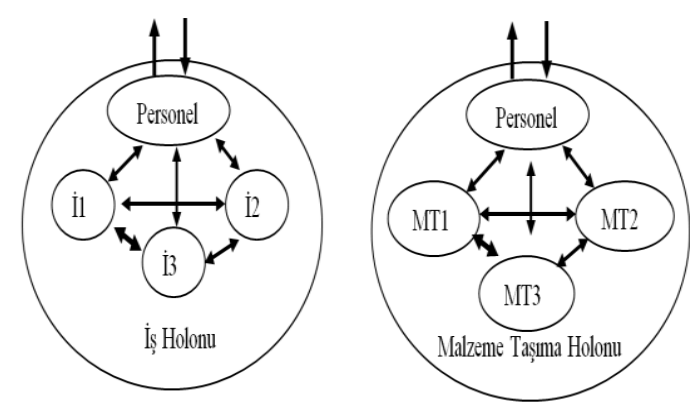

Şekil 2. İş ve malzeme taşıma holonun iç yapısı

Aralarındaki tek fark iş holonu mantıksal holon iken malzeme taşıma holonu fiziksel holondur. İş holonu dinamik bir yapıya sahiptir ve sisteme sipariş ulaştıkça iş holon sayısı artar. Malzeme taşıma holonu ise sistem de yer alan malzeme 
taşıma (MT) sistemlerinden oluşur ve hücreler arasındaki taşıma işlerinden sorumludur. Her iki holon da içerisinde personel etmen bulundurur. Personel etmen, holon dişındaki haberleşmeyi ve sisteme yeni iş ve malzeme taşıma etmeni eklenmesi ve çıkartılması görevlerini üstlenir.

Sistemde yer alan pazarlama holonu ise teslim zamanı etmeni ve sipariş etmeninden oluşmaktadır. Sisteme giren siparişler sipariş etmeni tarafindan alınır. Sisteme dahil olan siparişlere teslim zamanı etmeni tarafından teslim zamanı atanır ve üretim sistemine bırakılır (Şekil 1).

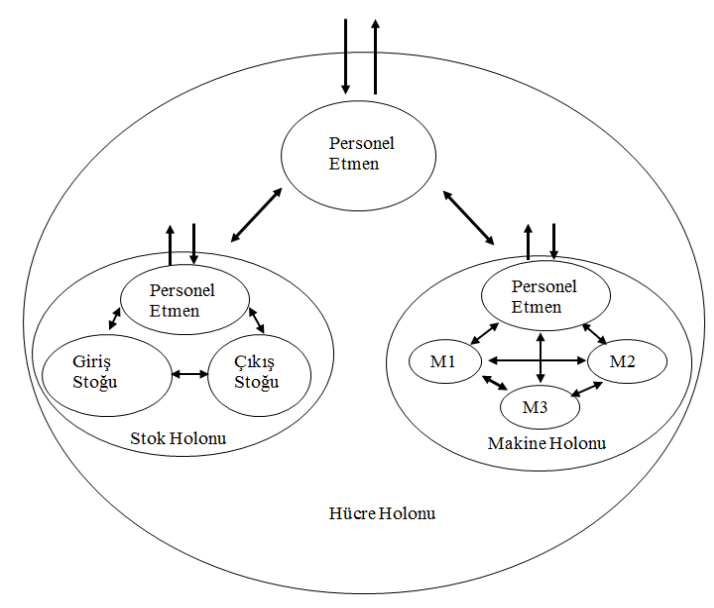

Şekil 3. Hücre holonun iç yapısı

Üretim sistemi içerisinde yer alan en önemli holonlardan birisi de hücre holonudur. Hücre holonlarının her biri fiziksel hücrelerden sorumludur. Buna göre her bir hücre holonu personel etmen, stok ve makine holonundan oluşmaktadır. Personel etmen hücre içi ve hücre dışı haberleşmeyi kolaylaştırmak için eklenmiştir ve arabulucu rol verilmiştir. Buna ilaveten sisteme hücre eklemesi ve çıkartılması personel etmen tarafindan yapılmaktadır. Personel etmen tüm alt holonlar içerisinde de yer almaktadır ve benzer görevi vardır. Makine holon ise alınan işlerin makinelere atanma işini gerçekleştirir. Makine holonu da kendi içerisinde fiziksel makinelerden ve personel etmenden oluşmuştur. Hücre holonunu oluşturan diğer bir holon da stok holondur. Stok holonuda kendi içerisinde giriş, çıkış ve personel etmenlerinden oluşmaktadır. Giriş ve Çıkış Stoğu etmenleri hücrenin giriş ve çıkış stok durumunu kontrol etmekte ve taşınması gereken malzemeler konusunda malzeme taşıma holonu ile haberleşmektedir. Önerilen hücre holonu yapısı Şekil 3' de verilmiştir.

\subsubsection{Holonik Sistemde Yer alan Etmenlerin İç Yapısı}

Etmen tabanlı yaklaşımların, sürekli değişen ortama sahip karışık etkileşimlerin ihtiyaç duyulduğu yerler için uygun olduğu kanıtlanmıştır. Etmen tabanlı sistemlerin en önemli özelliği her bir etmenin özerk sayısal varlıklar olmasıdır. Çevresini algılama özelliği ile birleștirilmiş olan özerklik özelliği, etmenlere kendi özelliklerine göre davranma, diğer etmenlerle iletişim kurma ve sistem kurucularına çok güçlü bir kapsülleşme imkânı sağlar. Bir etmen, hedefleri, bilgisi ve özellikleri bakımından tanımlanabilir ve daha sonra fonksiyonunu yerine getirmek için tasarlandığı çevre içerisinde özerk bir şekilde fonksiyonunu yerine getirmesi için serbest bırakılabilir. $\mathrm{Bu}$ dağınık sistemleri kurmak için etkili bir yoldur - sistemdeki her bir etmen, sistemdeki etmenlerle haberleşme, olaylara tepki verme ve kendi hedeflerinin peşinden gitmekle sorumludur. $\mathrm{Bu}$ şekilde, sistemdeki tüm etkileşimleri doğru bir şekilde programlamadan daha ziyade, sistemin yapı taşına oluşturan etmenlerin yeteneklerinin ve hedeflerinin bir ürünü olarak ortaya çıkan etkileşimlerin doğru şekilde programlanması önemli hale gelir.

Önerilen sistemde yer alan etmenler her biri kendine özgü içyapısı vardır. Bu yapı genel olarak kullandıkları planlar, olaylar (mesajlar) ve veritabanı yani inanç setlerinden oluşmaktadır (Şekil 4). Bu yapıda kullanılan ana bileşenler değerlendirme, haberleşme ve inanç setleri bileşenleridir. $\mathrm{Bu}$ bileşenler sayesinde her bir etmen değişen çevre şartlarına tepki verir, hedefleri doğrultusunda hesaplamalar yapar, veritabanına bilgi işler, veritabanından hazır 
bilgileri kullanır ve diğer etmenlerle veri alışverişinde bulunarak haberleşir. $\mathrm{Bu}$ yapı içerisindeki değerlendirme planları etmene diğer etmenlerden gelen istekleri değerlendirip hangi isteğin daha uygun olduğuna karar verme imkanı sağlar. Bunun yanı sıra haberleşme planları ve mesajlaşmalar kullanılarak sistem de yer alan diğer etmenlerle işbirliği ve haberleşmeler sağlanır. Böylelikle önerilen sistemde holonların özerkliği ve işbirliği mekanizması sağlanmış olur.

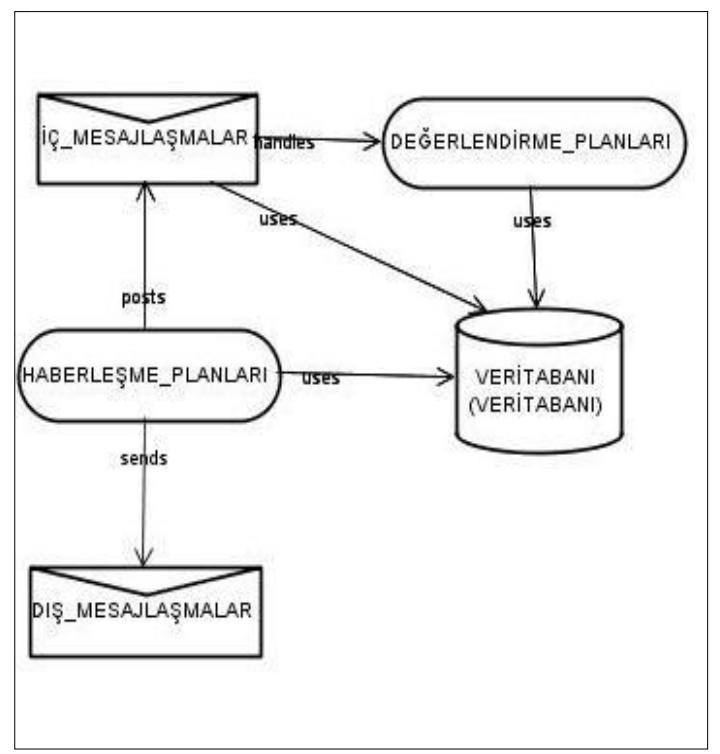

Şekil 4. Bir etmenin mimari yapı elemanları

Değerlendirme Planları: Holonik yapıda her ne zaman bir hesaplamaya ihtiyaç duyulursa etmen tarafından kullanılan planlardır. Değerlendirme planları iç veya dış çevreden gelen mesaj bilgilerini aldıktan sonra gerekli hesaplamaları yapar ve bu hesaplamalar yapıldıktan sonra etmen nasıl hareket edeceğine karar verir.

Haberleşme Planları: Haberleşme planları iç ve dış mesajlaşmayı kullanarak olaylar karşısında etmenin hangi tepkileri vereceğini karar vermek için kullandığı planlardır. Dış çevreden gelen mesajlar ilk önce haberleşme planı tarafında ele alınır ve gelen mesajın içeriğine göre ya direk cevap verilir ya da iç mesajlaşma kullanılarak değerlendirme planına gönderilir.
İç ve Dış Mesajlaşmalar: İnanç-İstek-Niyet (Belief Desire Intention-BDI) modelinde olaylar çevreden alınabilir ve aynı zamanda içsel olarak da yaratılabilir. Böyle içsel yaratılmış olaylar, hedefler gibi işlev görebilir.

Önerilen sistemde iki türlü haberleşme durumu söz konusu olacaktır. Bunlardan birincisi iç diğeri ise dış haberleşme yani diğer etmenlerle olan haberleşmedir. Bir etmen iç haberleşme sayesinde yeni bir olay yaratarak kendi veri tabanından sorgu yapabilecektir ya da farklı planlar devreye alınarak ek işleme tabi tutulmasını iç mesajlarla yapabilir. Dış haberleşmede ise diğer etmenlerle haberleşme sağlanır. Bir iş isteği gönderilirken dış mesajlaşma kullanılacaktır.

İnanç Setleri: Hücre, makine, iş, sipariş ve malzeme taşıma ile ilgili tüm bilgiler inanç setlerinde saklı tutulurlar. Bir işin hangi aşamada olduğu, makinelerdeki iş yükü durumu, makine uygunlukları gibi bilgiler her bir holon tarafindan kendi inanç setlerinde tutulur. İstenildiği zaman bu inanç setinden bilgi çekilir veya ekleme çıkarma yapilir.

\section{2. Önerilen Sistemin İşleyişi ve Teslim Zamanı Atama Süreci}

Önerilen bu holonik sistemde, yeni gelen bir iş ile ilgili karar alma sürecinde etkin rol oynayan varlıklar pazarlama, iş, hücre ve malzeme taşıma holonlarıdır. Önerilen bu sistemde pazarlama holonu yaratıldıktan sonra belirli bir zaman aralığında sipariş etmeni vasıtası ile işleri yaratmaya başlar. Bir iş yaratıldığı zaman bir sipariş etmeni, ilgili işe atanır. Sipariş etmeni aynı zamanda yeni yaratılan işi için bir operasyon listesi de oluşturur. $\mathrm{Bu}$ operasyon listesinde iş rotasının tanımlanmasının yanı sira operasyon sayısı da belirlenir. Sipariş etmeni tüm bunları belirledikten sonra bu bilgileri teslim zamanı etmenine gönderir ve bu iş için bir teslim zamanı belirlemesini ister. Teslim zamanı etmeni işin operasyon sırasına bakarak listedeki hücrelerle haberleşerek üretim sistemi ile ilgili bilgileri (Hücre giriş ve çıkış kuyruğunda ortalama bekleme süresi) temin eder ve o iş ile ilgili bir teslim zamanı belirleyerek 
sipariş etmenine bildirir. Teslim zamanı belli olan işler iş holonuna bildirilerek üretim sistemine bırakılır. İş holonuna bildirilen her yeni iş için iş holonu, yeni bir iş etmenine atar. İş holonu da o işi operasyon listesinde bulunan makinalar boyunca yönetir ve teslim zamanında önce işin tamamlanması için çalışır.

\subsubsection{Teslim Zamanı Atama Prosedürü}

Teslim zamanı etmeni, sipariș etmeni tarafından yeni bir teslim zamanı atanması isteğini aldıktan sonra geçmiş ve gelecekteki sistem yoğunluğu ve o sipariş ile ilgili özellikleri değerlendirerek o iş için bir teslim zamanı belirler ve bu belirlenen zamanı tekrar sipariş etmenine iletir.

Bir üretim sisteminde her bir işin genel iş akış süresi Eşitlik 1 ile hesaplanır.

$$
F_{i}=\sum\left(s_{i j}+m_{i j}+w_{i j}+p_{i}\right)
$$

Burada,

$\mathrm{i}=\mathrm{iş}$ tipi, $\mathrm{j}=$ istasyon numarası,

$S_{i j}=\mathrm{i}$-ninci iş için $\mathrm{j}$ - ninci istasyonda gerekli olan kurulum zamanını

$m_{i j}=\mathrm{i}$-ninci işin $\mathrm{j}$-ninci istasyondan bir sonraki istasyona taşıma süresi,

$w_{i j}=\mathrm{i}$-ninci işin $\mathrm{j}$-ninci istasyonda bekleme süresi

$p_{i j}=\mathrm{i}$-ninci işin $\mathrm{j}$-ninci istasyondaki işlem süresini temsil etmektedir.

Gerçek üretim sistemlerinde, işleme operasyonlarının çizelgelemesi gerçekleştirildikten sonra materyal taşıma operasyonlarını işleme operasyonları arasına sokmak ve bu yeni bilgiye göre çizelgeleme akış süresi tekrar hesaplamak gereklidir. Malzeme taşıma operasyonların da çizelgeleme, taşınması gereken işlerin sırasını verir ve belirli bir zaman döngüsü içerisinde taşıyıcıların işi alması ve dağıtması için taşıyıcı dağıtımı sağlar. Ancak çoğu klasik üretim sistemleri teorisi malzeme taşıma operasyonlarını ihmal ederek göz ardı eder. Eğer her operasyonun işleme zamanı herhangi bir malzeme taşıma operasyonundan çok büyükse ve malzeme taşıma kaynakları her ne zaman ihtiyaç duyulursa hazır olarak bulunabiliyorsa bu iyi bir varsayım olabilir. Ancak, gerçek üretim sistemlerinde, malzeme taşıma kaynaklarına ihtiyaç olursa malzeme taşıma kaynakları her zaman hazır değildir. Çünkü bu kaynaklar başka işleri yerine getiriyor ya da iş istasyonları arasında seyahat halinde olabilir. Bu sonuçlar, makinelerin yükleme ve boşaltma zamanlarında gecikmeyle ve işlere ait tamamlanma zamanları ve çizelge iş akış zamanında artış ile sonuçlanır.

$\mathrm{Bu}$ sebepten dolayı bu çalışmada malzeme taşıma sistemlerinin uygunluğundan kaynaklı olarak işlerin istasyon giriş (input) ve çıkış (output) kuyruğundaki beklemelerini göz önüne alan teslim zamanı atama formülü önerilmiştir (Eşitlik 2).

$\left.d_{i}=r_{i}+\sum p_{i j}+\sum m_{i j}+\sum w^{\prime}(i n)_{i j}+w^{\prime}(o u t)_{i j}\right)$

Burada,

$\mathrm{i}=\mathrm{iş}$ tipi, $\mathrm{j}=$ istasyon numarası,

$r_{i}=$ i-ninci siparişin serbest bırakılma zamanı,

$p_{i j}=\mathrm{i}$-ninci siparişin $\mathrm{j}$-ninci hücredeki işlem süresi

$m_{i j}=$ i-ninci siparişi bir sonraki hücreye taşımak için gerekli olan süre.

$w^{\prime}(\text { in })_{i j}=$ i-ninci işin rotasında olan $\mathrm{j}$-ninci istasyonun geliş kuyruğunda hesaplanan ortalama bekleme süresi.

$w^{\prime}(\text { out })_{i j}=$ i-ninci işin rotasında olan j-ninci istasyonun çıkış kuyruğunda hesaplanan ortalama bekleme süresi.

Holonik tabanlı teslim süresi atama modelinde her ne zaman sisteme bir sipariş girilirse bu formül kullanarak teslim süresi hesaplanır. Teslim zamanı etmeni tarafından gerçekleştirilecek olan teslim zamanı atama prosedürü aşağıdaki adımlardan oluşmaktır. $\mathrm{Bu}$ adımların gerçekleşmesi için gerekli olan etmen etkileşimleri de Şekil 5'de verilmiştir. 
Adım 1: Sipariş etmeni iş ile ilgili bilgiler alır (Operasyon siralaması, Beklenen operasyon süreleri(pij))

Adım 2: İş listesinde bulunan operasyon sıralamasına göre liste de bulunan istasyonlar ile haberleşerek sistemin genel durumu ile ilgili bilgiler elde edilir. $\mathrm{Bu}$ mesajlaşma sonunda hücreler istasyonların geliş ve çıkış kuyruğunda güncel olarak hesaplanan ortalama bekleme süreleri $\quad\left(w^{\prime}(\text { in })_{i j}, w^{\prime}(\text { out })_{i j}\right) \quad$ bilgilerini bildirirler.

Adım 3: Teslim zamanı atama etmeni, malzeme taşıma etmeni ile de haberleşerek beklenen taşıma süresi bilgilerini alır.

Adim 4:

$\left.d_{i}=r_{i}+\sum p_{i j}+\sum m_{i j}+\sum w^{\prime}(i n)_{i j}+w^{\prime}(\text { out })_{i j}\right)(3)$

kullanılarak teslim zamanı hesaplanan iș ile ilgili bilgiler sipariş etmene bildirilir.

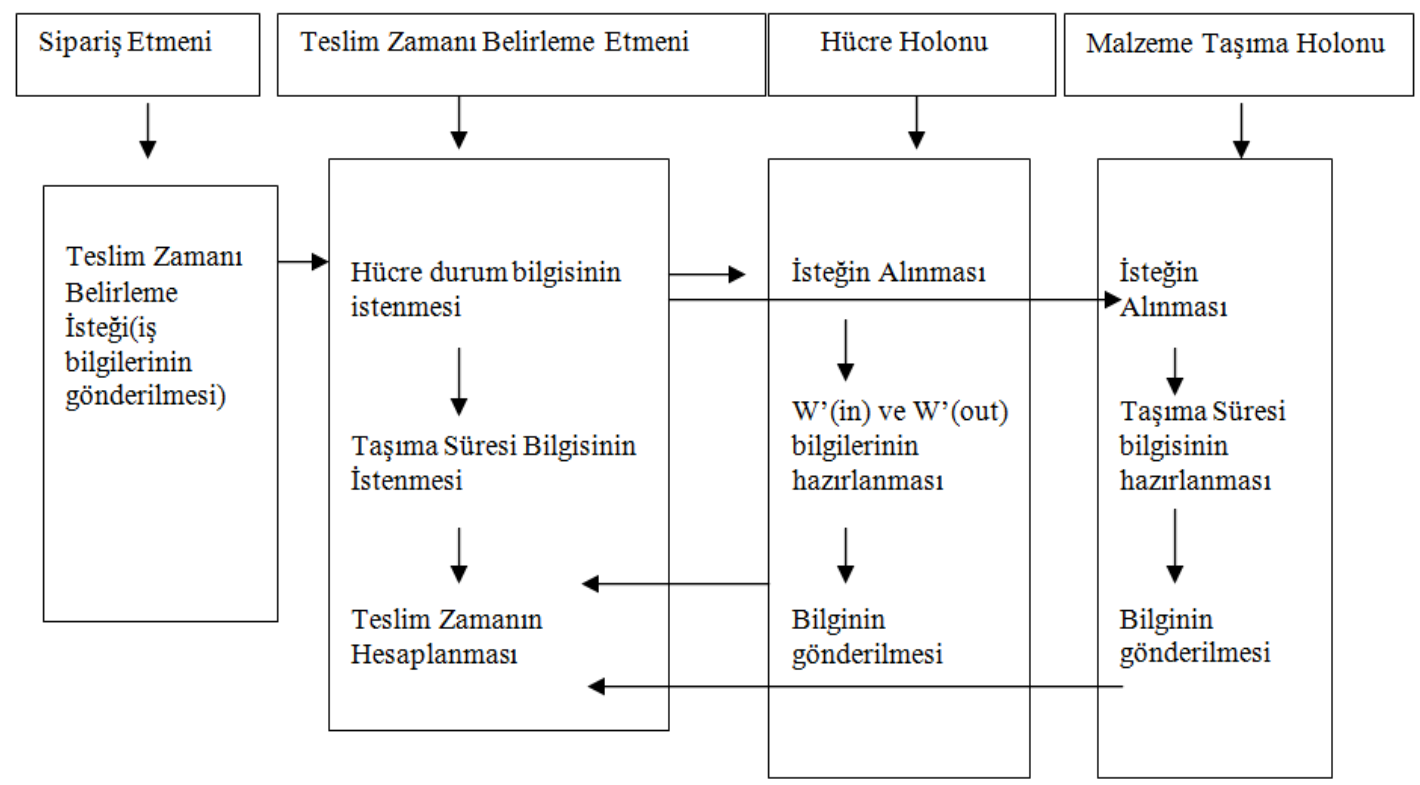

Şekil 5. Teslim zamanı atama prosedürü için holon ve etmen etkileşimleri

\section{SONUÇ VE ÖNERILLER}

$\mathrm{Bu}$ çalışmada bir esnek üretim sistemi içerisinde üretim süresinin önemli bir kısmını oluşturan makine işleme ve taşıma sürelerine etki eden makine gruplarını ve malzeme taşıma sistemlerini etkin bir şekilde çizelgelenmesi sağlayan ve gelen siparişlere bir teslim zamanı atayan holonik tabanlı bir kontrol yapısı önerilmiștir. Önerilen sistem esnek üretim yapan birçok işletme için etkin olarak uygulanabilir yapıdadır. Çoklu etmen sistemleri yazılımları, etmen tabanlı sitemleri geliştirme sürecini hızlı ve verimli şekilde kolaylaştırmaktadır. Bundan sonraki çalışmalarda önerilen bu kontrol yapısı, çoklu etmen sistemleri yazılımları üzerinde benzetim çalışmaları yapılarak literatürde önerilmiş olan diğer yaklaşımlarla performans karşılaştırılması yapılacaktır.

\section{TEŞEKKÜR}

$\mathrm{Bu}$ çalışma, Çukurova Üniversitesi Araştırma Fonu Bilimsel Araştırmalar Birimi MMF2011BAP23 numaralı proje olarak desteklenmiştir. 


\section{KAYNAKLAR}

1. Wang, J., Deng, Y., 1999. Incremental Modeling and Verification of Flexible Manufacturing Systems. Journal of Intelligent Manufacturing,. 10(6): p. 485-502.

2. Veeravalli, B., Rajesh, G., Viswanadham, N., 2002. Design and Analysis of Optimal Material Distribution Policies in Flexible Manufacturing Systems Using a Single AGV. International Journal of Production Research, 40(12): p. 2937-2954.

3. Jerald, J., 2006. Simultaneous Scheduling of Parts and Automated Guided Vehicles in an FMS Environment Using Adaptive Genetic Algorithm. The International Journal of Advanced Manufacturing Technology, 29(5-6): p. 584-589.

4. Philipoom, P.R., L. Wiegmann, Rees, L.P., 1997. Cost-based Due-Date Assignment with The Use of Classical and Neural-Network Approaches. Naval Research Logistics (NRL), 44(1): p. 21-46.

5. Alpay, Ş. N., 2009. Yüzügüllü, Dynamic Job Shop Scheduling for Missed Due Date Performance. International Journal of Production Research, 47(15): p. 4047-4062.

6. Baykasoğlu, A., Göçken, M., Unutmaz, Z.D., 2008. New Approaches to Due Date Assignment in Job Shops. European Journal of Operational Research, 187(1): p. 31-45.

7. Leitao, P., Restivo, F.J., 2008. Implementation of a Holonic Control System in a Flexible Manufacturing System. Systems, Man, and Cybernetics, Part C: Applications and Reviews, IEEE Transactions on, 38(5): p. 699-709.

8. Madureira, A., Santos, F., Pereira, I., 2008. Self-Managing Agents for Dynamic Scheduling in Manufacturing in Proceedings of the 10th Annual Conference Companion on Genetic and Evolutionary Computation. ACM.

9. Liu, J., Liu, J. J., Chen, Q. X., Mao, N., Lin, Z. A. 2011. A Multi-Agent-Based Mould Due Date Setting Approach in Stochastic Production. International Journal of Production Research, 49(5): p. 1353-1371.

10. Weeks, J.K., Fryer, J.S., 1977. A Methodology for Assigning Minimum Cost Due-Dates. Management Science, 23(8): p. 872-881.

11. Weeks, J.K., 1979. A Simulation Study of Predictable Due-dates. Management Science, 25(4): p. 363-373.

12. Baker, K.R., Bertrand, J., 1981. An Investigation of Due-Date Assignment Rules with Constrained Tightness. Journal of Operations Management,. 1(3): p. 109-120.

13. Smith, M.L., Seidmann, A., 1983. Due Date Selection Procedures for Job-Shop Simulation. Computers \& Industrial Engineering, 7(3): p. $199-207$.

14. Baker, K.R., 1984. Sequencing Rules and DueDate Assignments in a Job Shop. Management Science, 30(9): p. 1093-1104.

15. Ragatz,G.L, Mabert, V.A., 1984. A Framework for the Study of Due Date Management in Job Shops. The International Journal of Production Research, 22(4): p. 685-695.

16. Shanthikumar, J.G., Sumita, U., 1988. Approximations for the Time Spent in a Dynamic Job Shop with Applications to DueDate Assignment. The International Journal of Production Research, 26(8): p. 1329-1352.

17. Bector, C., Gupta, Y., Gupta, M., 1988. Determination of an Optimal Common Due Date and Optimal Sequence in a Single Machine Job Shop. The International Journal of Production Research, 26(4): p. 613-628.

18. Vig, M.M., Dooley, K.J., 1991. Dynamic Rules for Due-Date Assignment. The International Journal of Production Research, 29(7): p. 13611377.

19. Philipoom, P.R., 2000. The Choice of Dispatching Rules in a Shop Using Internally Set Due-Dates with Quoted Leadtime and Tardiness Costs. International Journal of Production Research, 38(7): p. 1641-1655.

20. Baykasoğlu, A., Göçken, M., 2009. Gene Expression Programming Based Due Date Assignment in a Simulated Job Shop. Expert Systems with Applications, 36(10): p. 1214312150.

21. Rajabinasab, A., Mansour, S., 2011. Dynamic Flexible Job Shop Scheduling with Alternative Process Plans: An Agent-Based Approach. The International Journal of Advanced 
Manufacturing Technology, 54(9-12): p. 10911107.

22. Y. Yin, S. R. Cheng, T. C. E. Cheng, C. C. Wu, W. H. Wu, 2012. Two-Agent Single-Machine Scheduling with Assignable Due Dates. Applied Mathematics and Computation, 219(4): p. 1674-1685.

23. Van Brussel, H., Wyns, J., Valckenaers, P., Bongaerts, L., Peeters, P., 1998. Reference Architecture for Holonic Manufacturing Systems: PROSA. Computers in Industry, 37(3): p. 255-274. 
